\title{
BIOGRAFIA INTELECTUAL DE BALDUINO ANTONIO ANDREOLA ${ }^{1}$
}

\author{
BALDUINO ANTONIO ANDREOLA INTELLECTUAL BIOGRAPHY \\ BIOGRAFÍA INTELECTUAL DE BALDUINO ANTONIO ANDREOLA
}

Balduino Antonio Andreola ${ }^{*}$

balduinoandreola@yahoo.com.br

RESUMO: Este artigo se constitui numa autobiografia intelectual do autor, relacionada necessariamente com sua história de vida ou sua biografia pessoal, a exemplo de vários grandes autores citados no texto. Sua trajetória acadêmica de docente e pesquisador, em várias universidades, foi inteiramente no campo da educação, com ênfase à educação popular, à educação do campo, aos movimentos sociais e ao diálogo intercultural. Suas preferências teóricas são por autores comprometidos com os excluídos, e com a construção de um mundo mais solidário.

Palavras-chave: Autobiografia. Educação Popular. Diálogo Intercultural.

ABSTRACT: This article is an intellectual autobiography of the author, necessarily related to his life story and his personal biography, like many great authors cited in the text. His academic career of teaching and research in various universities, was entirely in the field of education, with emphasis on popular education, rural education, social movements and intercultural dialogue. Their theoretical preferences are by authors committed to the excluded, and to building a more united world.

Keywords: Autobiography. Popular Education. Intercultural Dialogue.

RESUMEN: Este artículo se constituye en una autobiografía intelectual del autor, relacionada necesariamente con su trayectoria de vida o su biografía personal, a ejemplo de los diversos autores citados en el texto. Su trayectoria académica de educador einvestigador en distintas universidades fue enteramente en el campo de la educación, con énfasis a la educación popular, a la educación del campo, a los movimientos sociales y al diálogo intercultural. Sus preferencias teóricas provienen de autores comprometidos con los rechazados y con la construcción de un mundo más solidario.

Palabras clave: Autobiografía. Educación Popular. Diálogo Intercultural. 
* Doutorado em Ciências da Educação pela Université Catholic de Louvain (Bélgica). Professor no Programa de Pós-Graduação (Mestrado e Doutorado) do Centro Universitário La Salle - Unilasalle em Canoas-RS, na Linha de Pesquisa "Gestão, Educação e Políticas Públicas".

${ }^{1}$ Este trabalho contou com a participação da doutoranda em Educação, Pilar de Moraes Sidi, e do acadêmico do curso de Psicologia, Ronaldo Silva Lopes, ambos da Unilasalle Canoas-RS.

\section{INTRODUÇÃO}

O que está me sendo pedido, para a Revista Pedagógica da Unochapecó, é uma autobiografia intelectual, que não pode ser dissociada, evidentemente, de minha biografia pessoal ou de minha história de vida. Um exemplo dos mais eloquentes desta sociabilidade necessária eu a vejo em Paulo Freire, o maior pedagogo do nosso tempo, como o reconheceu Roger Garaudy. No meu discurso em homenagem a Paulo Freire, quando lhe foi outorgado o título de Doutor honoris causa na Universidade Federal do Rio Grande do Sul, eu citei o texto do livro Conscientização, onde ele escreveu:

Em Jaboatão perdi meu pai. Em Jaboatão experimentei o que é a fome e compreendi a fome dos demais. Em Jaboatão, criança ainda, converti-me em homem graças à dor e ao sofrimento que não me submergiam nas sombras da desesperação. [...] Em Jaboatão, quando tinha dez anos, comecei a pensar que no mundo muitas coisas não andavam bem. Embora fosse criança comecei a perguntar-me o que poderia fazer para ajudar aos homens. (FREIRE, 1979, p. 14).

Prosseguindo na minha fala, eu disse que via, naquela experiência de Jaboatão, a arqueologia da Pedagogia do Oprimido, não apenas como livro, mas, sobretudo, como projeto pedagógico-político de toda a sua vida. Mais tarde li, em vários textos seus, que ele próprio reconhecia naquela experiência da fome, a raiz mais remota daquela que seria a opção radical e definitiva de sua vida.

Depois de falar das origens ou da arqueologia da obra e dos compromissos pedagógico-políticos de Freire, não poderia esquecer que a história da obra e dos engajamentos de Emmanuel Mounier é muito semelhante a de Freire. Mounier escreveu em seu livro Revolução Personalista e Comunitária:
Uma nova juventude havia nascido um pouco endurecida, um pouco simplificada, pode ser, em seus gestos ainda inadaptados: mas ela viu a miséria, e sua vida foi por ela transformada. A prosperidade permite o jogo e mascara a injustiça. A miséria aperta o homem sobre seus problemas essenciais e desvela em grandes proporções os pecados de um regime. A experiência ou a proximidade da miséria, este foi nosso batismo de fogo. [...] A miséria passou, com seu cortejo de grandezas. Esta é a chave. Todo aquele que não experimentar primeiramente a miséria como uma presença e uma queimadura dentro de si mesmo, nos fará objeções vãs e polêmicas falsas. (MOUNIER, 1961, p. 132-133). 
Estas palavras finais da citação de Mounier cabem, na medida certa, às críticas levianas de alguns filósofos de nossas universidades, que em sua vaidosa prepotência, descartam sumariamente Mounier como filósofo menor, sem ter entendido nada do alcance histórico de sua obra, como Ernani M. Fiori soube proclamar, na sua defesa perante a Comissão de Inquérito que promoveu sua cassação na UFRGS, em 1964 (FIORI, 2014, p. 312-318).

Em outra obra, Mounier fala de sua geração como uma geração órfã, referindo-se aos horrores da primeira guerra mundial, que dizimou quase inteiramente a geração dos homens da anterior à sua.

Paul Ricoeur, grande amigo de Mounier, também se refere a esta orfandade. Num livro que resulta de uma entrevista com Edmond Blattchen, a um dado momento o entrevistador pergunta a Ricoeur: "Seu balanço do século XX é apesar de tudo nitidamente negativo, não?” E Ricoeur responde:

O medonho século XX, como gosto de dizer, se o fizermos começar em 1914 e de certo modo terminar em 1989 com a queda do muro de Berlin. Compreende ainda assim duas grandes guerras, e acontece-me de dizer com Vaclav Havel - estou muito próximo dele nisso - que é quase mais importante, paradoxalmente, do que a segunda guerra mundial, porqueéo suicídio da Europa. (RICOEUR, 2002, p. 32).

Logo mais adiante o entrevistador comenta: "O senhor viveu diretamente, como ator, este século XX. Em 1915, o senhor perdia seu pai; entre 1940 e 1945 viveu no cativeiro..."

Ricoeur, na sua grandeza de homem e de historiador, responde, quase laconicamente: "Sim. É muito, insignificante em relação à deportação dos judeus" E o entrevistador reconhece: "É mérito seu considerar os acontecimentos dessa maneira” (RICOEUR, 2002, p. 34).

$\mathrm{O}$ interesse de Ricoeur por temas ligados à história tem muito a ver, creio, com as experiências dolorosas das duas guerras.

A escolha do objeto de minha tese de doutorado, do qual falarei mais adiante, cujo objeto foi uma aproximação crítica entre as obras de Mounier e de Freire, tem muito a ver com minha biografia pessoal. E o meu interesse pela obra de Paul Ricoeur foi também motivado pela trajetória intelectual dele, marcada pela amizade profunda com Mounier e com a filosofia do Personalismo. Ao falar de Ricoeur, não posso esquecer o grande privilégio que tive de ter sido vizinho dele, quando de meu estágio de um mês na Biblioteca Mounier, em Châtenay-Malabry, cidade periférica de Paris, 1983.

Já que falei de três grandes intelectuais muito presentes em minha biografia acadêmica, acrescentarei um quarto 
ainda. Trata-se do filósofo Ernani Maria Fiori. Como em outras oportunidades, também em palestras mais recentes, lembrei que não fui nem aluno, nem colega de Fiori, e que meu interesse por sua obra estava muito mais ligado à influência importante dele na obra de Freire, à amizade profunda entre os dois e à grande parceria entre eles, sobretudo durante os vários anos do exílio que os tornou vizinhos e parceiros de luta, no Chile.

Tendo sido convidado, recentemente, para uma fala sobre a obra de Ernani Fiori, na Faculdade de Educação da UFRGS, a Diretora daquela instituição, Professora Simone, disse que considera Fiori um clássico, e lembrou que os clássicos são definidos como "atemporais". Eu considero, pois, da minha parte, os quatros autores de minha preferência, Freire, Mounier, Fiori e Ricoeur, atemporais. Não obstante, há uma observação importante a fazer, mesmo com relação aos clássicos, e eu a expressei quando Paulo Freire esteve pela última vez na UFRGS, em 1995. No dia 18 de maio ele cumpriu a promessa feita, no ano anterior, de que viria para "um papo com os estudantes". Pouco antes do meio dia, enquanto eu fiquei assando os galetos, o Prof. Fernando Becker foi buscá-lo no aeroporto. Naquele dia foi para mim e para minha família uma grande alegria receber Paulo Freire para almoçar conosco. De tarde, os estudantes valorizaram magnificamente a vinda dele, lotando o salão de atos da UFRGS, onde cabem três mil pessoas, com muitos sentados nos degraus das escadas.

No dia seguinte, ele aceitou ir para o seminário que eu ministrava no PPG/EDU da UFRGS. Após sua fala, expressei minha posição, estudioso de sua obra, nestas palavras: "Paulo, eu vou dizer aqui, na tua presença, o que eu já disse muitas vezes, em palestras ou aulas: "Eu nunca quis e nunca quererei fundar o clubinho do Paulo Freire". E expliquei: "Todos os grandes pensadores, entre os quais eu te vejo, foram ou são intelectuais de horizontes abertos a outras linhas de pensamento, em diálogo amplo com outros intelectuais. Mas nós, muitas vezes, os reduzimos à dimensão de nossa capela, de nosso clubinho, de nossa igrejinha". Na sua resposta ele disse: "Balduino, gostei que tu não queres fundar o timinho do Paulo Freire". Feita esta ressalva, quero dizer, porém, que considero uma iniciativa minha das mais importantes de toda a minha trajetória, a de ter proposto a criação do que conhecemos hoje com o nome de "Fórum de Estudos: Leituras de Paulo Freire". Eu disse desde o início que, se o Fórum surgisse, seria criação coletiva, Ninguém seria dono do projeto, nem estrela maior. E assim está sendo até hoje, desde 1998, quando coletivamente o criamos, durante um Congresso Internacional, na UNISINOS. Cada ano é sediado numa universidade diferente. Neste ano o fórum realizou sua XVII sessão anual na Universidade Federal de Santa Maria. Naquela sessão estiveram quarenta participantes vindos de Chapecó. Em 2016, o Fórum será em Jaguarão, mas em 2017 emigrará para o Oeste de Santa Catarina, sendo sediado por 
uma universidade da região, certamente em parceria com suas vizinhas.

Minhas escolhas de temáticas ligadas aos movimentos sociais, como MST e Movimentos Negros, à educação do campo e à educação popular, tem muito a ver com os autores citados, mas, ao mesmo tempo, com minha história de vida. Retomando, pois, a ideia inicial deste artigo, de uma relação necessária entre minha biografia intelectual e a pessoal, prosseguirei narrando simultaneamente as duas, ou seja, minha história de vida e minha trajetória de educador andarilho perene, por muitos caminhos e várias atividades muito diferentes, marcadas por momentos belos e gratificantes, mas também por outros não tanto. Antes de iniciar esta minha "biobibliografia" reli uma longa entrevista que fizeram comigo quatro orientandos meus de doutorado e dois outros colegas de Universidade, para um livro intitulado Memórias e Sonhos de Educador: homenagem a Balduino Antonio Andreola.

Naquela entrevista, eu me defini como o "menino tímido da colônia perdido na cidade grande”. Eu amo o silêncio, a paz, tenho saudade das paisagens bucólicas do interior. Mesmo nos tempos de minha formação para o sacerdócio cheguei a pensar em ser monge beneditino. Não sei por que a vida me reservou tantas situações polêmicas, e tristes às vezes. O livro foi organizado por Celso Ilgo Henz, da UFSM e Gomercindo Ghiggi, da UFPel. Participaram, com eles, como entrevistadores, Felipe Gustack da UNISC, Humberto Calloni da FURG, José Fernando Kieling (falecido) da UFPel, e Fabio Purificação de Bastos da UFSM. Naquele diálogo com meus entrevistadores fui levado às minhas origens, em Fazenda Souza, hoje sétimo distrito de Caxias do Sul. Mas quando nasci, pertencia ao sétimo distrito de São Francisco de Paula de Cima da Serra, sediado em Vila Seca. Caxias do Sul comemora 2015, 140 anos de sua história, ligada à vinda dos primeiros imigrantes italianos. Mas Fazenda Souza tem suas origens muito mais remotas, com uma história de mais de trezentos anos, quando se denominava "Pouso Alto", porque era o lugar de pousada de tropeiros, que vinham de São Paulo, quando o transporte de mercadorias era feito através de mulas.

Filho de João Angelo Andreola e de Thereza Gubert Andreola, sou o primeiro de onze filhos. Meu pai era agricultor. Amava a fruticultura e viticultura. No nosso parreiral, além de uvas comuns, como a Isabel, cultivava umas trinta variedades de uvas finas, tendo sido contemplado com o primeiro prêmio, na Festa da Uva de Caxias do Sul, em 1937. Mas não havia condições de comercialização do que era produzido. Meu pai foi convidado, em 1946, a construir, em Caxias do Sul, uma chácara para o falecido Júlio Eberle, e de fato construiu uma chácara modelo, que continuou cultivando por vários anos. O plano dele era ganhar um bom dinheiro para comprar um terreno em lugar melhor, como conseguiu. Mas quando o pai pensou numa mudança para lá, minha mãe disse: “Os maiores estão 
trabalhando, os do meio, estudando, e nós não podemos ir para a roça com os pequenos". O sonho de meu pai de voltar ao cultivo da terra, que ele amava, terminou aí. Com o avanço da urbanização, em Caxias, a chácara teve que ceder às construções imobiliárias. E meu pai trabalhou dezoito anos como ronda noturno da Metalúrgica Abramo Eberle.

Da minha infância não guardo muitas recordações. Lembro a catequese preparatória à Primeira comunhão, na então capela de Nossa Senhora da Saúde, hoje paróquia há muitos anos. Meu pai, sendo o primogênito de sua família, com a morte de meu avô paterno, assumiu com a mãe dele, a administração da casa paterna, onde eu e mais dois irmãos e duas irmãs nascemos e moramos até 1941, creio, quando meu tio Verino casou e nós nos transferimos para a casa nova, morando, porém, bem pertinho da casa da avó. Eu não conheci meu avô paterno, como também não conheci o avô materno, ambos falecidos muito cedo. Na família de minha mãe eram doze irmãos. Sendo que os dois primeiros eram homens, e a terceira da lista estava sempre doente, coube a minha mãe ajudar minha avó a cuidar de sete irmãozinhos e uma irmãzinha. Ela não pôde assim frequentar a escola e alfabetizar-se.

Minha escolarização inicial e a do meu irmão Nilo foi à escolinha municipal da vila de Fazenda Souza, que frequentei, se bem lembro, em 1940 e 1941. Fui alfabetizado com uma cartilha da qual só lembro duas lições, até porque me suscitaram muita estranheza. Uma se intitulava "O Baú", e a outra "A Juba". A professora lia em voz alta, destacando muito as sílabas: Ooobaaa-uuu... E nós alunos repetíamos, em coro: Ooobaaa-uuu... Eu não sabia o que era baú. Olhava para aquela figura, e pensava: cadeira não é, cama também não. Não podia entender que alguém deitasse dobrado. Hoje sei que era baú de canto. Na outra lição, a professora lia: Aaaajuuuu-baaa é do leee-ão. E nós soletrávamos: Aaaajuuubaaa-é-do-leão... Eu não entendia o que era aquela cabeleira enorme, não sabia o que era o leão. Hoje entendo, com Paulo Freire, que aquilo era "invasão cultural”. Nada a ver com minha cultura camponesa.

Só agora, depois desta reminiscência pitoresca, consegui conscientizar a razão remota da escolha, em 1979, de meu primeiro projeto de pesquisa na Universidade, sobre as Cartilhas de Alfabetização. Nele nos perguntávamos, minhas alunas e eu, se cartilhas feitas no Rio ou em São Paulo seriam adequadas para a alfabetização de crianças das periferias de Sapucaia do Sul, de Esteio, de Canoas e de Porto Alegre.

Meu irmão Nilo e eu íamos à escola andando três ou quatro quilômetros a pé, até a vila. Quando o tempo estava chuvoso e a estrada de chão ficava barrenta, tínhamos que carregar os tamancos na mão. Na entrada da vila a gente limpava os pés com um pano, e calçava os tamancos para entrar na sala de aula. Na hora do recreio, deixávamos os tamancos de lado, para correr e brincar mais livremente. Um dia uma colega pegou meus tamancos. Na aula 
seguinte eu via, à minha esquerda, os meus inconfundíveis tamancos nos pés de minha colega. Mas eu era tão tímido, que pedia quase licença para existir, e não tive coragem nem de reclamar com a colega, nem de fazer queixa com a professora. Confesso, porém, que tenho saudades até hoje dos meus tamancos de sola de madeira.

As aulas eram de manhã. De tarde, desde pequenos, lá no interior, a gente ajudava em serviços de casa, mas sabíamos também usar uma enxadinha, para capinar as ervas e pequenos arbustos, que iam invadindo o terreno, onde cresciam o milho, batatas doces, batata inglesa, feijão, abóboras, tomates, e outras culturas de nossas roças. Com oito ou nove anos já me cabia, às vezes, ir ao moinho montado a cavalo. As distâncias variavam. Para o moinho da Cooperativa Agrícola, em Ana Rech, eram dez ou onze quilômetros. Ao vilarejo de Boca da Serra, a distância era um pouco maior. Na vila de Fazenda Souza, bem mais perto, havia um moinho, que foi desativado, creio que em 1940 ou 41. Às vezes tinha que ir para um moinho perto da capela de Santo Omobom, perto de São Braz, a terra do Tite, técnico do Corinthians. Era o trajeto que eu mais temia, porque havia umas descidas muito íngremes, e era quase certo que abarrigueira afrouxasse, e então a sela ia para o pescoço do cavalo ou da mula. Nas minhas andanças eu caí três vezes. Duas vezes do cavalo, e outra de uma mulinha xucra. Eu vinha voltando sonolento, por causa do sol da tarde, e não lembrei que havia uns urubus saboreando uma carniça, à beira da estrada. No que a mulinha apareceu na curva da estrada, as "elegantes" aves carnívoras levantaram estrondosamente voo, eu já estava no chão.

Quando meus filhos, Diego e Michel, eram pequenos, e íamos visitar meus pais, hoje falecidos, em Caxias, enquanto, minha esposa Tânia e eu ficávamos falando com o pai e a mãe, meu mano Luiz levou meus filhos para um passeio de carro, e aproveitou para contar a eles que eu dormi no lombo do cavalo, ou da mulinha, as três vezes, por isso caí da sela, e continuei dormindo no meio da estrada. E enquanto isso a minha montaria foi embora. Até hoje, não me adianta contar a eles como foram minhas quedas, porque para eles só vale a versão de meu irmão.

$\mathrm{Eu}$ cresci, desde cedo, num ambiente intercultural, pois Fazenda Souza se situa nas imediações entre a "colônia", como se denominava a região rural, e os campos "de Cima da Serra”. Vila Seca, Vila Oliva e Santa Lúcia do Piaí, já se situam no campo. De maneira que eu convivi, desde criança, com uma população que em casa só falava "italiano", e a que só falava português, denominado "brasilero", pelos da origem italiana. E mesmo as famílias de origem italiana tinham proveniências diferentes. Nós, os Andreola, éramos chamados feltrini, oriundos da região pré-alpina de Feltre, na Itália. Os Mazochi eram de Mântrua. Os Lorandi tinham suas origens na região de Trento, e o pessoal os denominava: Toni Trento, Batista Trento etc., como se Trento fosse o sobrenome. Os Viganó eram da Lombardia, 
e a gente não os chamava Viganó, mas sim "Milanês", novamente como se fosse o sobrenome. As formas dialetais divergiam muito. Dessas misturas de dialetos e do português criou-se quase um novo idioma, como é documentado em pesquisas realizadas por Freire Rovilio Costa e Arlindo Batistel, no livro intitulado Cosi parla italiani - Assim falam os italianos.

$\mathrm{Eu}$ reconheço em minhas heranças culturais esta mescla das minhas origens. Da cultura italiana, além do italiano estudado no seminário e aperfeiçoado mais tarde, ao cursar a Teologia na Itália, trago o amor, por exemplo, à poesia gauchesca, tendo como guru inspirador o pajadorrepentista Jayme Caetano Braun. De vez em quando eu arrisco umas trovas gauchescas como quando, durante o doutorado na Bélgica, desabafei minha saudade num poemeto guasca que começava assim:

Eu tenho uma alma campeira,

E quando acordo as lembranças

Adoro as velhas andanças

Nos caminhos da emoção.

Nos espaços sem porteira

Parece que eu tenho asa,

E volto pra minha casa,

Que eu amo de coração.

E na última estrofe, em tom campeiro, eu me despedia:

Vou voltar pra minha gente...

Lá no bairro ou lá na roça,

Prefiro andar de carroça,

Na estrada cheia de pó,

Pois não tem nego que aguente,

Neste mundo que anda torto,

Só pensando no conforto,

Todo mundo anda só.

Mas sem esquecer o italiano rústico da infância, lembrei-me também com saudade daquele coral variado e misterioso, com que as rãs e os sapos rompiam o silêncio profundo das noites do interior, e joguei minha interpretação daqueles cantos palustres num poemeto onomatopaico intitulado Rane e Rospi, do qual extraio aqui alguns versos:

Qua-qua-qua-qua-qua...

Ze i rospiche canta.

Qui, qui, qui, qui, qui:

Le ranele salta.

Qua, qua, qua, qua, qua, Qui, qui, qui, qui, qui:

L'è tuta la note

Sto imenso corale,

Che scende e chesale,

De in mesoal palude.

Nessumos'ilude:

No basta cantare...

Bisognacatare

Qualcuno o qualcuna,
Qua, qua, qua, qua, qua: Son mi chehociamà... Qui, qui, qui, qui, qui, Rospeto, son mi. L’imensocorale El tase um minuto. La lunalavarda... L'amoreècompiuto.

Zequesta na storia De rane e de rospi. Se storie de gente Le ze diferente No sodirghegnente. 
Per poter amare.

Ma amare con chi,

Se l' rospol'èrospo

E no ghezerospa,

La ranal'èrana

Eno ghezerano?

Che mondo bem strano...

Poaretistirospi,

Poaretesterane.

Fazenda Souza, minha terrinha querida, além de sua história gloriosa de mais de trezentos anos, teve também alguma história pitoresca, como esta que vou contar. Eu costumo dizer que as mulheres não precisam da lei Maria da Penha, para defender seus direitos, porque basta a "Maria da lenha", como aconteceu com dona Marieta, se bem lembro o nome. O Gigio (Luiz no dialeto local), marido dela, não gostava de cansar-se demais no trabalho da roça, preferindo deixar para a mulher e os filhos. Aos domingos, então, montava a cavalo e ia pra vila bater uns papos valentes com os amigos. A mulher em casa matava uma galinha, mas só podia fazer, para ela e os filhos, uma sopa com o caldo da galinha. A carne tinha que ficar para ele, quando voltasse à noite. Um domingo, porém, ela e os filhos resolveram saborear não apenas a sopa, mas também a carne da galinha. Evidente que sobraram somente os ossos.

À noite o marido chegou esporeando o cavalo, apeou e foi entrando em casa, já com aguinha na boca, só de pensar em sua tradicional galinha "lessa". Sendo que nada via sobre a mesa, levantou a voz, reclamando: "Véia, tô com uma baita fome. Cadê minha galinha?” A mulher já tinha separado o melhor pedaço da lenha destinada ao fogão, e tocou-lhe uma exemplar sumanta de pau. Mudando o tom da voz, ele foi logo suplicando: "Era só brincadeirinha, brincadeirinha!" Mas a mulher só parou ao completar a dose certa. Algum tempo depois houve um batizado. Não lembro se a criança era da Marieta e do marido, ou se eles eram os padrinhos. O almoço dos pais, dos padrinhos e de alguns tios ou amigos foi no único hotelzinho da vila. No meio da festa, um dos presentes foi perguntando: "E então, Gigio, foi só brincadeirinha, só brincadeirinha?"

Em 1941 foi construído, em Fazenda Souza, o Seminário Josefino, destinado à formação, no terceiro e quarto ano primário e no curso ginasial de outros tempos, dos candidatos à Congregação dos Padres Josefinos do Murialdo. No dia 26 de setembro de 2015 houve em Fazenda Souza, uma confraternização de ex-seminaristas, com o lançamento do livro organizado por Jaime Dall'Alba, comemorativo dos 75 anos daquele Seminário, onde estudei de 1942 a 1948, e mais tarde, fui professor, em 1953, 1954, 1955, e de 1960 a 1966. Trata-se de um volume de 533 páginas, com 32 coautores, entre josefinos até hoje e ex-seminaristas. 
Minha formação, em nível superior foi, resumidamente, como segue. Em 1950, 1951 e 1952, o Curso de Filosofia no Seminário Central de são Leopoldo, dirigido pelos Padres Jesuítas. Todos os professores que tive eram muito cultos e competentes, mas a filosofia era inteiramente escolástica e livresca, ministrada em latim. Notei, mais tarde, que fez muita falta a leitura dos grandes clássicos da filosofia, e a abertura às contribuições da filosofia moderna e do nosso tempo, correntes todas julgadas com severidade quase que dogmática, a partir da Escolástica. Não obstante estas lacunas, fomos educados para o rigor dos métodos de estudo.

Após os três anos de exercício do magistério, uma praxe de várias congregações religiosas, fui para a Itália, onde cursei os quatro anos de Teologia no Instituto San Pietro, seminário então internacional da Congregação à qual pertencia. Lá fui ordenado sacerdote no mês de março de 1959.

Na minha tese de doutorado eu escrevi que o Curso de Teologia, exceto o da Exegese e Teologia Bíblica, não me ajudaram em nada nas minhas atividades pedagógicas e pastorais, ou para minha espiritualidade. A Teologia dogmática era totalmente na linha da visão pré-conciliar, sistematizada em manuais, no formato de proposições ou teses, a serem provadas, a partir da Bíblia e dos documentos oficiais da Igreja. Na História da Igreja, ministrada pelo professor considerado o mais competente em termos de conhecimento, as aulas eram totalmente expositivas, e numa ótica inteiramente eurocêntrica. O professor de Teologia Moral fazia um esforço enorme para ministrar a disciplina numa perspectiva menos "moralista" de uma "teologia do pecado", numa ótica do sermão da montanha, mas a organização legalista e prescritiva dos estudos, de acordo com o "Ordinamento General e degli Studi", não abria espaço para respiros mais livres. Quanto à moral do sexto e do nono mandamentos, no campo da sexualidade humana, mesmo com toda a boa vontade de um homem marcado pela bondade, fica-me a lembrança de que não se conseguiu superar a visão maniqueísta da qual o próprio Santo Agostinho parece que não se livrou.

Quanto ao Direito Canônico, nunca consegui entender por que a Igreja precisava de tantas leis. Eram 2414 artigos, seguidos de vasta Legislação Complementar. O Direito Canônico representava uma Igreja Católica concebida como instituição, como sociedade hierárquica. O Concílio Vaticano II, em todos os seus documentos, nos convidou a redescobrir a Igreja como Comunidade de irmãos, como Povo de Deus. Mas a realização concreta do Vaticano II é ainda um sonho bastante distante. O Papa João Paulo I tentou mudanças profundas, mas sua morte misteriosa, após 33 dias de pontificado, interrompeu bruscamente suas iniciativas. Com o Papa Francisco estamos respirando uma nova aurora de esperanças e de mudanças profundas. Se a Encíclica Evangelii Gaudium - Alegria do Evangelho, segundo ele próprio diz, a escreveu "aos membros da 
Igreja, a fim de mobilizá-los para um processo de reforma missionária ainda pendente", na Carta Encíclica Laudato Si’ - Louvado sejas, um documento que está tendo grande repercussão mundial sobre o grave problema do meio ambiente, ele declara: "Nesta encíclica, pretendo especialmente entrar em contato com todos acerca da nossa casa comum" (PAPA FRANCISCO, 2015, p. 10).

Fiquei na duvida se inserir ou não estes dados bastantes polêmicos, quanto à minha formação e minha trajetória, como religioso e sacerdote. Tendo tido oportunidades para conhecer, através de minhas variadas andanças, várias universidades, dei-me conta de quanto são numerosos os egressos de seminários e de casas de formação de congregações religiosas masculinas e femininas. Neste sentido achei que meus depoimentos podem contribuir para debates e pesquisas sobre estes problemas, tanto para os que permanecem, quanto para os egressos.

Além das muitas mudanças em andamento, esperamos que o Papa Francisco consiga extinguir o Estado do Vaticano, que me parece se constituir num anacronismo histórico, e num contratestemunho do Evangelho. Afinal de contas, Jesus Cristo não quis ser soberano terreno, e usou uma pedagogia muito sábia para convencer aos poucos os apóstolos de que ele não viera para restaurar o Reino de Israel, e de que seu Reino, para o qual os estava convidando, não era deste mundo. Como justificar então, com base no Evangelho de Jesus Cristo, que o Papa seja soberano terreno?

Como membro do Conselho Provincial da Congregação à qual eu pertencia, mostrei a urgência de todos os confrades realizarem os cursos de licenciatura, sendo que a Congregação se dedica também ao ensino em colégios, além de seus seminários. Eu próprio reingressei na Universidade. Teria preferido uma licenciatura em letras, tendo sido, em meu magistério, sobretudo professor de Português e de Literatura. Não podendo, porém, frequentar um curso de letras, resolvi voltar à Filosofia. Não sendo reconhecido pelo MEC o Curso Seminarístico, cursei novamente três anos pela UNISINOS, e o quarto ano, na Faculdade Nossa Senhora Medianeira, de São Paulo. Sou assim um evadido das letras. Costumo dizer que acumulei tantos prefixos "ex" em minha vida, que hoje não quero acrescentar nenhum "pós", até porque há um gosto sôfrego de "pós": pós-moderno, pós-piagetiano, pós-estruturalista, pós... Lembro que Jean-Marie Domenach, terceiro diretor da revista "Esprit", ironizava os modismos de sua época. Ao dizer que muitos consideravam o "Personalismo" superado, ele, sem se preocupar muito com tal "desatualização", respondeu que não era de se estranhar, sendo que Paris mudava de modismo a cada dois anos.

Enquanto eu concluía meu segundo Curso de Filosofia, veio o reconhecimento, por parte do MEC, do Curso Seminarístico, acrescido apenas de um ano de complementação pedagógica. Lembro que Aristóteles perguntava: 
“É melhor fazer filosofia ou ganhar dinheiro?” Depois de responder que é mais nobre fazer filosofia, acrescentou que, se você precisa sobreviver, é melhor que vá ganhar dinheiro... Se ele soubesse dos meus sete anos de Filosofia iria me dizer: "Que é mais nobre fazer Filosofia, tudo bem, mas não precisava exagerar”.

Assim mesmo, na Bélgica, quando fui saber se poderia fazer meu doutorado em filosofia, fiquei sabendo que precisaria fazer um curso preliminar tão exigente, que me exigiria, creio, mais dois anos de filosofia, e então me decidi pelo Doutorado em "Ciências da Educação", como é denominado o curso realizado por mim na Faculté de Psychologie et des Sciences del>Education, na Université Catholique de Louvain, em Louvain-la-Neuve (Bélgica). Minha tese, intitulada "Emmanuel Mounieret Paulo Freire: Une pédagogie de la personne et de La communauté" foi uma aproximação crítica entre a obra de Freire e de Mounier, na busca de afinidades e complementariedades, como contribuições para uma filosofia da pessoa e da libertação.

Citei o título de minha tese em francês por dois motivos. Um como denúncia do colonialismo linguístico, e outro porque não consegui ainda publicar minha tese em português e não sei se irei publicar. Quanto ao colonialismo linguístico, lembro que um dia, durante meu curso, tendo ido falar com o Prof. Michel Bonami, com quem tinha entabulado já um excelente diálogo e bons vínculos de amizade, perguntei a ele: "Vejo que o senhor tem aqui, em sua sala, várias teses e dissertações em espanhol. Por que de nós, brasileiros e portugueses, exigem que escrevamos em francês?" E ele me respondeu: "O espanhol tem status internacional que o português não tem.”

O tema do colonialismo sempre me interessou muito. Trata-se de um tema que tem a ver com o problema da opressão e com uma pedagogia política da libertação, nas obras de Freire e de Mounier. Acho interessante, aliás, dizer algo, "en passant", sobre duas dúvidas que precisei resolver, na escolha de minha tese. A primeira, a mais importante e mais difícil, quanto a escolha do objeto de pesquisa. Guardo ainda algumas anotações, nas quais eu estava em dúvida se, em lugar da escolha que fiz, não poderia optar por um estudo sobre as contribuições de Hegel para a Educação. Uma tese sobre Hegel, evidente que me daria mais status na academia... Mas não era esta minha preocupação. Acho até que aquela dúvida foi quase irrisória. Não conheço a fundo a obra de Hegel. Meus conhecimentos ligam-se mais ao estudo da História da Filosofia do que à leituras, muito reduzidas, de obras suas. Sem negar que Hegel seja um dos maiores filósofos da modernidade, com influências profundas não só na filosofia, mas também na ciência política, no direito, na psicologia e na educação, tenho dele uma visão muito crítica quanto aos seus preconceitos enormes, diria até grosseiros, com relação aos povos da África e da América Meridional, hoje denominada América Latina. Tais preconceitos foram amplamente expressos em suas 
aulas de Filosofia da História, ministradas nos últimos anos de sua vida, na Universidade de Berlim, publicadas postumamente no livro que tenho em espanhol intitulado "Lecciones sobre La Filosofía de la Historia Universal" (HEGEL, 1980).

Sobre esta temática escrevi um capítulo intitulado: Dos preconceitos de Hegel ao Diálogo das Civilizações, no livro organizado por meus orientandos de doutorado na UFRGS, e publicado numa nova edição, reformulada em parte, e acrescida com textos de outros autores convidados (ANDREOLA et al., 2012).No meu capítulo reformulei apenas um tópico, do publicado na primeira edição. Alguns colegas respondiam às minhas críticas contra os preconceitos de Hegel, dizendo que ele, como outros, na Europa do seu tempo, não dispunha de informações suficientes sobre a África e a América Meridional. Mas eu havia lido um texto de Michel Montaigne, no seu livro Ensaios, escrito ao menos 250 anos antes que Hegel escrevesse seus horrorosos preconceitos. O texto a que me refiro é o capítulo XXXI de seu famoso livro. Naquele capítulo, Montaigne dedica longas páginas a uma fala interessantíssima e nada preconceituosa com relação às terras "descobertas" pelos espanhóis. Referindo-se à denominação de "bárbaros" ou "selvagens", com que os colonizadores caracterizavam aqueles povos. Ele escreve:

[...] não vejo nada de bárbaro ou selvagem no que dizem daqueles povos; e, na verdade, cada qual considera bárbaro o que não se pratica em sua terra. [...] Por certo, em relação a nós são realmente selvagens, pois entre suas maneiras e as nossas há tão grande diferença que ou o são ou o somos nós. (MONTAIGNE, 1972, p. 105 e 108).

Montaigne baseia suas reflexões em informações obtidas com pessoas que conheciam o "Novo Mundo". Ele escreve que teve a seu serviço, "durante muito tempo", um homem que permanecera dez ou doze anos na região do "Novo Mundo" à qual Villegaignon dera o nome de "França Antártica”. Relata ainda que três indígenas estiveram em Ruão, quando lá se encontrava Carlos IX, e que falou com um deles. A respeito dos valores culturais daqueles povos, citarei ainda um fragmento muito significativo de sua obra:

Transcrevi aqui um de seus cantos guerreiros: pois tenho também uma canção de amor: 'Serpente, para, para, serpente, a fim de que minha irmã copie as cores com que te enfeitas; a fim de que eu faça um colar para dar à minha amante; que tua beleza e tua elegância sejam sempre preferidas entre as demais serpentes'. É a primeira estrofe e o estribilho da canção; ora, eu conheço bastante a poesia para julgar que este produto de sua imaginação nada tem de bárbaro, antes me parece de espírito anacreôntico. Aliás, a língua que 
falam não carece de doçura. Os sons são agradáveis e as desinências das palavras aproximam-se das gregas. (MONTAIGNE, 1972, p. 109).

Minha tese de doutorado eu a defendi na Bélgica no dia 13 de maio de 1985 , e iniciei, assim, referindo-me à data: "No dia de hoje, em meu país, é a data oficial da abolição da escravatura. Eu disse "oficial", porque para a abolição de todas as formas de escravidão, no Brasil e no mundo, há ainda um longo caminho a percorrer. E para este empreendimento, os dois autores que estudei em minha tese deram uma contribuição muito valiosa”. Após a defesa, um grande amigo hoje falecido, Prof. Dorivaldo Poletto, da PUC/RS, que iria defender sua tese no campo da Sociologia, me disse: "Balduino, não precisavas dizer aquilo, no início de tua tese, num país estrangeiro". E eu respondi: "Poletto, eles conhecem melhor do que nós nossas contradições históricas".

Falei de tantas coisas, neste meu escrito, indo, vindo e voltando, mais num estilo de associação livre, do que de um esquema ou plano lógico. E nessas mudanças nômades, não falei quase nada de minha "biografia" de educador, ou, mais, especificamente, de professor há 62 anos. Como membro de uma Congregação religiosa e sacerdote católico, acho que procurei ser sempre educador, mesmo não estando em sala de aula. Como professor, lecionei dois anos no quarto ano primário, denominado "curso preparatório", porque preparava para o ginásio ou para o normal de nível ginasial, que formava professores para o meio rural. No ginásio lecionei Português, Francês e Religião. No segundo grau lecionei Português, no seminário, e Filosofia e Psicologia da Educação, num curso de magistério. No Estado, fiz concurso em Filosofia, no início dos anos 70, mas sendo o tempo da ditadura não pude lecionar Filosofia, e então me confiaram as disciplinas de Moral e Cívica, Religião e Relações Humanas. No curso superior, minha disciplina era Filosofia da Educação, além de Metodologia do Ensino de Filosofia, na qual fiz também concurso na Universidade de Caxias do Sul. Mas um dia fiz uma lista das disciplinas lecionadas em três Faculdades, em meia década, não meio século, de 76 a 81, e somaram 21, não por minha opção, mas porque as instituições precisavam. Hoje eu denomino, jocosamente, esta dispersão como uma "pedagogia simiesca”, porque são os símios, os macacos que pulam de galho em galho. Ao ser convidado para planejar, com outros colegas, um Mestrado em Educação, na Escola Superior de Teologia da Igreja Luterana, em São Leopoldo, lecionei lá, durante seis anos, disciplinas ligadas tanto à Educação quanto à Teologia, e orientei cinco Teses de Doutorado em Teologia e duas dissertações também.

$\mathrm{Na}$ área da Educação foram bastante numerosas as orientações de Mestrado e de Doutorado, sobretudo na UFRGS, mas também na UFPel (Pelotas), como professor visitante, e hoje no UNILASALLE de Canoas. 
Na Congregação Religiosa, minhas atividades de professor foram em certos momentos interrompidas, ou reduzidas, por atividades mais diretamente no campo pastoral, ou por compromissos de direção e de participação em Comissões ou Assembleias, no caso dois Capítulos Gerais. $\mathrm{Na}$ Universidade Federal do Rio Grande do Sul interrompi quase totalmente a docência, quando fui Diretor da Faculdade de Educação, de dezembro de 1988 a dezembro de 1992. O meu predecessor, Prof. Alceu Ferraro, foi eleito, naquele, como primeiro da lista sêxtupla. Mas o Presidente Sarney, que também não foi eleito para aquele cargo, não respeitou a vontade da comunidade universitária, nomeando o terceiro da lista, o qual havia prometido publicamente que não aceitaria se não fosse o primeiro.

Ao ser eleito como primeiro na chapa vencedora para Diretor, alguns amigos me diziam: "O Reitor não vai te nomear, porque tu apoiaste as manifestações dos estudantes contra a sua posse." Mas ele nomeou os primeiros, nas 24 unidades, até para se legitimar. Antes da posse solene, ele quis uma conversa com cada um dos nomeados. Na reunião comigo ele me disse, logo de início: "O senhor vai ter uma tarefa difícil, a de pacificar a Faculdade de Educação, onde está havendo muitos conflitos." Eu respondi: "O senhor tem razão de que há conflitos naquela Faculdade. São conflitos de ordem ideológica ou filosófica, quanto a diferentes concepções de educação ou de sociedade, e quanto a diferentes teorias e autores, no campo da educação. Mas acho que não cabe a mim uma missão quase messiânica de pacificar a Faculdade de Educação. Somos todos adultos, por isso acho que se trata de um aprendizado a fazermos em conjunto, debatendo em alto nível nossas diferenças, nos respeitando, ao mesmo tempo, como pessoas. Infelizmente, às vezes a coisa resvala para o nível pessoal”. Mas depois de responder a proposta pacifista dele, me senti perante a uma responsabilidade. Não pude titubear, e complementei minha resposta acrescentando: "Reitor, já que o senhor falou em 'pacificar', não acharia necessária uma pacificação em nível de Universidade? O senhor sabe a que me refiro: o inquérito da Policia federal, que o senhor pediu para instaurar contra os estudantes, quando ocuparam a sala do Conselho Universitário, na sessão de sua posse”. Ele encaixou bem e me disse: "O senhor tem razão. Quando a Polícia Federal terminar a investigação e entregar à Justiça, vou pedir à Justiça que arquive”. Eu observei, então: "Será um gesto que só poderá engrandecê-lo, porque os estudantes, com sua inteligência, suas grandezas, seu espírito de luta; com seus problemas, seus defeitos, seus exageros, são "nossos estudantes", possivelmente, nossos filhos. Se não soubermos ajudá-los a enfrentar seus problemas, e chamarmos a polícia ou o exército, é uma derrota para nós”.

Antes da posse solene dos novos diretores, no Salão de Atos, houve a transmissão de cargo, na Faculdade de Educação, com um discurso breve do meu predecessor, e 
depois minha fala, também breve, na qual relatei igualmente a primeira reunião com o Reitor, e minha resposta à sua sugestão de que me caberia "pacificar a FACED". Terminada a transmissão do cargo, o Prof. Tomaz Tadeu da Silva me disse: "Tu foste corajoso, hein". Eu retruquei: "Não me parece que tenha sido um ato de coragem. Pelo contrário, seria da minha parte covardia se, para tirar média com o Reitor, eu me calasse, enquanto os estudantes, que confiaram em mim, estavam respondendo inquérito, e poderiam até ser expulsos da Universidade".

Gesto de coragem foi talvez o que me levou a retirar, em 1992, meu nome, contado como certo na Assembleia dos Movimentos Docente, Discente e dos Servidores, que decidiu a chapa depois vencedora, na eleição para Reitor da UFRGS.

Muitos anos antes, como religioso, tive que enfrentar o visitador de Roma, para evitar a expulsão injusta de vários jovens religiosos, dos quais eu era formador. Paguei um preço doloroso por minha decisão, mas não me arrependo do que fiz. Penso apenas que há ocasiões na vida em que omitir-se é covardia, que nos desautoriza a falar, depois, em compromisso com a ética, com a justiça, com a verdade.

Saldo positivo que me ficou daquelas decisões, de enfrentar o superior vindo de Roma e o Reitor imposto pelo Sarney, foi o de me imunizar para sempre, creio, contra qualquer aceitação ou tolerância passiva para com instituições ou posturas autoritárias. Como consequência coerente com isso, minha afinidade com autores cuja biografia e cujas obras trazem a marca da luta contra todas as formas de opressão, a favor de processos de libertação e democracia.

Devo reconhecer que, além dessas experiências de impacto, o que me ajudou muito, num processo meu de libertação, ainda que parcial e provisória, de minhas amararas, foi o curso "Christus Sacerdos", três anos de terapia pessoal, na linha da Psicanálise, e os cursos do Movimento de Criatividade Comunitária ou Cibernética Social (DE GREGORI, 1984), quase difundiram muito, no Brasil, no fim dos anos sessenta e na década de 70. Eu participei daqueles cursos, nos vários níveis, sendo depois autorizado a ministrá-los.

Num mundo ocidental, que julga ter construído a maior civilização da história, numerosos intelectuais do nosso tempo o veem caminhando para formas sempre mais sofisticadas de barbárie. Neste mundo Ocidental, que escolheu como projeto único do desenvolvimento a globalização idolátrica do mercado, está comprovado que os mercados mais rentáveis são: o comércio de armas, o tráfico de drogas e, vergonhosamente, o tráfico de seres humanos.

Frente à ameaça de destruição da própria vida no planeta, não podemos renunciar, com Paulo Freire, a um projeto político-pedagógico da Esperança (FREIRE, 1992), e com o Papa Francisco (2015), a uma luta para a qual lança um apelo de grande impacto, não somente aos católicos, mas a todos os moradores desta casa comum, o Planeta 
Terra, em sua encíclica ecológica "Laudato Si" (Louvado Seja). Associando-me esperançosamente ao seu brado, concluiria com uma ode ecológica, apresentada em Porto Alegre, no $3 .^{\circ}$ Fórum Social, em janeiro de 2003:

\section{GRITO DE MÃE}

Eu sou a Mãe Terra Cansada de guerra, De ódio e violência, A minha aparência Não é mais aquela Da mãe grande e bela, Que Deus quis e fez. Pra muitos em vez De casa e jardim, De mãe até o fim, Sou vil propriedade. No campo ou cidade Vendida ou comprada, Ferida, estuprada, A mãe já não sou, E o filho de outrora, Meu dono de agora, Virou gigolô... Com passos incertos, De braços abertos, Tateando no escuro, Meus filhos procuro E os quero de volta,
Da mesa em volta, Do ódio esquecidos, $\mathrm{Na}$ casa reunidos, Sem medo e sem fome Que a muitos consome Do imenso cansaço Dos longos caminhos, Voltai, meus filhinhos, Ao meu grande abraço. Anseio de novo $\mathrm{O}$ amor de meu povo. Que encontre em mim A casa e o jardim, A Mãe que Deus quis Formosa e feliz, A Mãe que Deus fez Pra todos vocês. Pra todos vocês.

\section{REFERÊNCIAS}

ANDREOLA, Balduino Antonio. Diálogos com Paulo Freire: ensaios sobre a educação, cultura e sociedade. Balduino Antonio Andreola, Celso Ilgo Henz e Gomercindo Ghiggi (Orgs.). - Pelotas: Ed. da UFPEL, 2012.

Carta Encíclica do Sumo Pontífice FRANCISCO. Laudato Si (Louvado sejas): sobre o cuidado da casa comum. São Paulo: Paulus \& Edições Loyola Maria, 2015.

DE GREGORI, W. Cibernética social I: um método interdisciplinar das ciências sociais. São Paulo: Cortez, 1984.

FREIRE, Paulo. Conscientização: teoria e prática da libertação uma introdução ao pensamento de Paulo Freire/ Paulo Freire [tradução de Kátia de Mello e Silva; revisão técnica de Benedito Eliseu de Leite Cintra]. São Paulo: Cortez \& Moraes, 1979.

FREIRE, Paulo. Pedagogia da Esperança: um reencontro com a pedagogia do oprimido/Paulo Freire. Rio de Janeiro: Paz e Terra, 1992.

HEGEL, George Wilhelm Friedrich. Lecciones sobre La filosofía de la historia universal. Madrid: Alianza Editorial, 1980. 
Memórias, diálogos e sonhos do educador: homenagem a Balduino Antonio Andreola. Celso Ilgo Henz e Gomercindo Ghiggi (Orgs.). Santa Maria, 2005.

MONTAIGNE, Michel de. Ensaios. São Paulo: Abril Cultural, 1972.

MOUNIER, Emmanuel. Oeuvres. v. 1. Paris: Éditions Du Seuil, 1931-1939.

RICOEUR, Paul. O único e o singular. Entrevista com Edmond Blattchen. Tradução de Maria Leonor F. R. Loureiro. São Paulo: Editora UNESP; Belém, PA: Editora da Universidade Estadual do Pará, 2002. 